\title{
Actors, epistemic communities and policy change: analysis of the solid waste policy in Guarulhos (SP)
}

\author{
Cristiane Kerches da Silva Leite \\ Lígia Gonçalves De Lócco
}

${ }^{I}$ Professor at the School of Arts, Sciences and Humanities at Universidade de São Paulo (EACH/ USP), Graduate Program on Social Change and Political Participation (PromusPP); São Paulo, SP, Brazil..

${ }^{1 I}$ Bachelor in Environmental Management (EACH/USP) and Master in Public Policy Management by the Graduate Program in Public Policy Management from EACH/USP; Guarulhos, SP, Brazil.

\begin{abstract}
This article analyzes the formulation and implementation of the solid waste policy in the city of Guarulhos, with an emphasis on the political process of disputing ideas, interests and instruments of public policies between political actors, epistemic communities and public managers. This research problematizes how the municipality of Guarulhos was a pioneer in the development of the Municipal Solid Waste Plan. The objective was to articulate analytical categories of public policy making to discuss the political role of a network of actors from the solid waste epistemic community in the change of policy in Guarulhos. Through the analysis of secondary data (bibliographic research) and primary data (decrees, laws, minutes of meetings and interviews with strategic actors), it is possible to verify the process of changing the image of the solid waste policy, especially regarding the issue of civil construction waste disposal, through the transfer and learning of specialists acting as political actors in the subsystem of this policy.
\end{abstract}

Keywords: Solid waste; public policy; epistemic community; public policy image

São Paulo. Vol. 23, 2020

Original Article

DOI: http://dx.doi.org/10.1590/1809-4422asoc20190024r2vu2020L6AO 


\section{Introduction}

This article addresses the process of formulating and implementing the solid waste policy in the city of Guarulhos, SP, specifically analyzing the political process of disputing ideas, interests and instruments of public policies between political actors, epistemic communities and public managers, based on analytical categories of public policies ${ }^{1}$. The choice of this case study is justified in that it is the first municipality to submit the Municipal Solid Waste Plan to the Ministry of the Environment (Decree No. 31513 of 26.12.2013) ${ }^{2}$. It is argued that this is not a process of federative induction (ARRETCHE, 2012) in which the federal entity coordinates the municipalization of national social policies, such as those of health and education, but the result of dynamics initiated in the late 1990s, involving institutional processes and of circulation of political and epistemic communities inside and outside the municipality.

The perennial political element in the process of building the municipal plan in Guarulhos was the continuity of the political group of the Municipal Executive from 2001 to 2016. It is argued that this continuity contributed to the stability of the political dynamics of the process of setting the waste policy in the municipal plan. Thus, the municipal protagonism in the context of the setting of the national waste policy is noteworthy, in the perspective of a type of Brazilian federalism where the federal plan has historically assumed responsibility for the federative coordination of various social policies (MACHADO; PALOTTI, 2015; ARRETCHE, 2012; MACHADO, 2014; LEITE; FONSECA, 2011; SOUZA, 2005).

Until the 2000s, the formulation and implementation of solid waste policies in Brazil were municipal prerogatives and there were no national guidelines. The National Basic Sanitation Policy - PNSB (Law No. 11.445/2007) represented an important normative advance for urban cleaning, by defining planning as essential functions of the management of public basic sanitation services. The Municipal Plan was designed as a fundamental instrument in the implementation of water supply, sanitary sewage, rainwater drainage, urban cleaning and solid waste management services. The approval of the Federal Basic Sanitation Law resulted in the preparation of the first municipal basic sanitation plans in a national context. Prior to the PNSB, there were resolutions by the National Environment Council (CONAMA), which deal specifically with some types of waste.

In 2010, after about 20 years of processing, the National Solid Waste Policy - PNRS (Law No. 12,305/2010) was approved and incorporated other types of waste such as those from civil construction, health services, agroforestry, among others. In addition, it highlighted the need for municipalities to formulate plans in an articulate manner with the PNSB, so that the municipal plan for integrated management of solid waste can be included in the basic sanitation plan (art. 19, § 1, of Law No. 12,305, 2010), respecting the minimum content provided for in the PNRS ${ }^{3}$.

2- See: https://www.guarulhos.sp.gov.br/legislacao-pertinente-residuos-solidos

3 - PNRS encourages and vetoes practices in waste management, as well as establishing priorities in waste management. 
The implementation of the National Policy encountered challenges at the local level. Before the existence of this legal framework, municipalities developed divergent waste management practices in relation to the new regulations set in the National Policy, such as controlled dumps and landfills, in which more than half of the municipalities disposed of their waste in 2010. As of 2014 these became illegal. In addition, the National Policy determined that municipalities should develop plans for integrated waste management, establishing deadlines for the implementation of guidelines and priorities at the local level as conditionalities for access to federal resources.

There were three historic moments in waste management in Guarulhos. Until the 1970s, there was no public service in the municipality; between 1971 and 2000, the residential waste collection service was provided by a company contracted in regions of the municipality (with priority for the central region). The final disposal involved smallholdings with pig raising or dumps. Between 2001 and 2016, an integrated waste management policy was structured and developed, with programs for the reuse, recycling and final disposal of waste in landfills, the period in focus in this study.

The aim of this text is to analyze the relationship between political actors and epistemic communities ${ }^{4}$ (HAAS, 1992; CAPELLA; BRASIL, 2015) in Guarulhos, with an emphasis on the circulation of ideas and the transfer of public policies (PORTO DE OLIVEIRA; PIMENTA DE FARIA, 2017). Specifically, we sought to discuss the articulation of actors from external epistemic communities, bureaucracy and local politicians to formulate and implement a public policy, more specifically the solid waste management policy, which overflowed the borders of the municipality through entrepreneurial action (KINGDON, 2011) of actors legitimized by their epistemic insertion, in a network of specialists.

The research methodology consisted of analysis of secondary qualitative data (bibliographic research) and primary data (decrees, laws, minutes of meetings and, above all, interviews with strategic actors in the process of implementing the solid waste policy in the municipality of Guarulhos). The chosen timeframe was the period for structuring the policy, between 2001 and 2016. There were 21 semi-structured interviews and participant observation in events on the topic inside and outside the municipality. The 21 interviews are described and parameterized in the master's thesis that generated this work. Specifically for the purposes of the analysis that generated this article, 11 interviews were used. To preserving the anonymity of the interviewees, each was identified by a code: the letter "I" followed by a number, according to the chronological order of completion ${ }^{5}$. The choice of interviewees followed the snowball technique (BALDIN; MUNHOZ, 2011), where each respondent indicated three other potential interviewees. This technique was important for building the network of relevant actors in the solid waste management subsystem in Guarulhos.

The construction of the object involved identifying historical dynamics of the process of institutionalization of urban cleaning in the municipality since the 1990s,

4- The concept of epistemic community is defined in the theoretical framework section.

5. See list of interviewees in the appendix. 
only accessible via reports from the actors who experienced the processes. Likewise, we sought to identify the network of actors in a relational perspective (movements, alliances, disputes, ideas and interests), especially between 2001 and 2016. Thus, the analysis of the interviews aimed to map the actors who took part in the political process under analysis, to determine which ones were strategic, how they moved in the political arenas, and which ideas contributed to the process. The analysis of the minutes of the meetings also aimed to identify the actors involved, their ideas and possible disputes. In the case of the analysis of decrees and laws, we sought to understand the institutional framework of the policy, as well as specific technical guidelines.

\section{Theoretical framework}

The theoretical framework of this study is based on analytical categories of public policies that refer to the dynamics of actors and the articulation of ideas and public policies (PERISSINOTTO; STUMM, 2017), highlighting the notions of public policy subsystem (SABATIER; JENKINS-SMITH, 1993; BAUMGARTNER; JONES, 1993; HOWLETT et al., 2013); epistemic community (HAAS, 1992); political learning (HALL, 1993); governmental and entrepreneurial policy agenda (KINGDON, 2011), circulation and transfers of policies (PORTO DE OLIVEIRA; PIMENTA DE FARIA, 2017), image and monopoly of public policies (BAUMGARTNER; JONES, 1993). The analytical assumption is that the context and the interpretive dimension of the actors are important elements in public policy configuration, just as ideas (worldviews, paradigms, causal stories, representations, images, among others) count for the creation of meanings about public policies. In this way, the post-positivist and cognitive view is privileged analytically ${ }^{6}$.

From the outset, one must consider that the process of producing public policies is complex and does not end with the idea of a linear and sequential cycle, which would involve the formulation, implementation and evaluation of public policies. According to Howlett et al. (2013) the analysis of conflicts and disputes between actors and their ideas and interests, in several institutional arenas that run through the heuristic stages of the public policy cycle, can be performed from the analytical category of the public policy subsystem ${ }^{7}$, which comprises a space for articulation and interaction of actors in networks, communities and/or coalitions around a public policy theme.

Some authors define the subsystem as a dimension that lies between the macrosystem (the dimension of political clashes configured more broadly) and the microsystem (the space for technical clashes between specialists), composed of a limited number of actors and institutions, relatively cohesive with each other, who dedicate efforts to specific issues within policies (CAPELLA; BRASIL, 2015). The historical perspective of the

6 - On post-positivism and cognitive analysis, see: FISCHER; FORESTER (1993); DRYZEK (1990); MAJONE (1989); CAMPBELL (1998; 2002); BÉLAND; COX (2011); GOLDSTEIN; KEOHANE (1993); HALL (1993). For national analytical works: BARCELOS (2012; 2015); TOMAZINI; LEITE (2016); GRISA (2012); LEITE; FEIJÓ; ROSIN (2018). 7 - For a discussion of the history and polysemy of the public policy subsystem concept, see CAPELLA; BRASIL (2015). 
analysis of the subsystem of the solid waste policy in Guarulhos made it possible to analyze the process of building this policy over time, articulating dynamics between actors who moved between the macro and the microsystem, with emphasis on the circulation of the epistemic community of waste management.

In this work, the fundamental role of a technical team external to Guarulhos was verified, I\&T, a consultancy firm in the area of waste, which operated in the formulation, implementation and transfer of ideas about waste policies, acting as an epistemic community (HAAS, 1992), that is, capable of producing and providing information that governments demand. By playing an important role in advising decision makers who work in uncertain scenarios, communities are strengthened as political actors, beyond the technical dimension.

The change of government in 2000 changed the contextual political dimension of the Executive in Guarulhos, opening the possibility of changing the agenda through the entry of new ideas about solid waste management (KINGDON, 2011). In that favorable political scenario, consultants were able to act as an epistemic community, that is, as political actors who have the legitimacy to advise decision makers and assume delegated responsibilities, mobilizing their causal beliefs, values, notions of validity of knowledge and techniques for public management (HAAS, 1992, p. 03). In this way, they are potential protagonists of social learning processes (HALL, 1993) by accumulating past experiences and conducting them in the form of new ideas for different institutional and political contexts, in processes of transfer of public policies.

According to Porto de Oliveira and Pimenta de Faria (2017), diffusion and circulation studies are dedicated to analyzing broad and fluid processes of displacement of ideas about public policies, with the difference that diffusion involves political dynamics across countries, regions and municipalities. Transference studies, in turn, aim to understand how paradigms, designs, institutional arrangements, instruments (among other elements) of a public policy (or specific program) move to another context. It is a more specific look, while the focus of diffusion and circulation studies is broader. In this study, it is interesting to highlight that the circulation of specialist political actors from an epistemic community brought about a process of transferring experiences that had the municipality of Guarulhos as a platform for other municipalities, even influencing the PNRS debate in the Federal Government.

Kingdon (2011), author of the agenda setting theory called Multiple Streams, provides analytical categories that allow discussing the process of changing government agendas in which contextual, contingency and ideational dimensions are important. Generally speaking, an issue becomes an object of government attention from a political process of understanding that it is a government problem. Therefore, for Kingdon (2011), problems do not have an intrinsic and a priori raison d'être, but they are built through understanding generated in a political process of dispute between the actors. Likewise, government agendas can change in very specific circumstances, which can be contingent (such as a disaster, a crisis), due to policy evaluation feedback or changes in indicators, or government changes arising from political dynamics (such as terminations 
and beginning of mandates).

The possibility of change can become concrete depending on the political dynamics that affect the processes, which can be mobilized by pressure groups or by the action of the so-called public policy entrepreneur ${ }^{8}$. According to Kingdon (2011), in the processes of change there may be the action of a political actor who makes a difference. It is a governmental or societal actor, investing resources (time, energy, reputation, money) to promote a position in exchange for anticipating future gains in the form of material benefits, oriented towards their goals. It may also be an expert on a certain issue and a skilled negotiator, who plays the role of spreading ideas, promoting the encounter of problems and solutions and taking advantage of political moments, or windows of opportunity, to make changes. In this paper, it is argued that a specialist from an epistemic community acted as a policy entrepreneur in the setting of solid waste policies in Guarulhos, as will be discussed below.

Finally, from Baumgartner and Jones's (1993) model of "punctuated equilibrium" agenda setting, this work mobilized the concepts of image and monopoly of public policy. The authors advance with respect to Kingdon's theory by considering the political dimensions of ideas, the role of specialists and institutional arenas more centrally. The stability, or the "freezing," of some policies would be related to the control over the policy discourse, that is, the interpretation of a problem can operate as a mechanism that provides stability, configuring "policy monopoly." In monopoly situations, the problem is addressed only within technical communities, power groups and political subsystems, restricting the emergence of new ideals, proposals and participants, in a condition of "negative feedback." In Guarulhos, the political groups interested in the monopoly on the management of rubble through the cata-treco program acted in a repeat manner, vetoing changes in this public policy instrument.

However, conditions of change, of breaking the "policy monopoly," may arise with the construction of a new understanding of the policy, a new image. This process of building the new image of the policy defines a new institutional context, a favorable arena for its diffusion. The new image of the problem and the new arena would be able to break the "equilibrium" situation, attracting actors and proposals, thus taking the problem to the decision agenda (macrosystem). After this process, with the implementation of the formulated policy, a new balance point would be generated. The empirical research that bases this work allows us to affirm that the case of the change of the solid waste policy in Guarulhos, which will be approached next, is characterized by the central role of an epistemic community in the construction of a new image that mobilized the shift of the debate about residues and debris from the microsystem to the macrosystem, that is, to the decision-making arena.

In the next section, the theoretical framework presented will be articulated with the empirical information generated through the interviews and government documents analyzed. The analysis of the data allowed to identify a network of actors that comprised

8- Like the concept of a public policy subsystem, that of a political entrepreneur is also polysemous. For more details see: CAPELLA (2016). 
the solid waste management subsystem in Guarulhos: the director of the Guarulhos Urban Cleaning Department from 2001 to 2011; the director of I\&T consultancy; the coordinator of the Gea Institute; the secretary of Public Services; the mayor of Guarulhos from 2001 to 2008; the head of the Selective Collection Division and the head of the Household Collection Division of the Department of Urban Cleaning; the biologist of the Department of Urban Cleaning since 2002 and the president of the company Quitaúna.

\section{Analysis development}

In the 1990s, the regular household waste collection service in Guarulhos was restricted. The collected waste was taken to a dump in an area of preserved forest. The other types of waste had no collection or public disposal service (construction and demolition waste, for example) and were deposited on the streets and vacant lots. There was a small municipal administrative structure, with a waste management policy that was limited to the collection, transportation and disposal services at the household waste dump, carried out by the company Quitaúna, contracted by the Municipality.

At the end of the decade, there was a turning point, with the approach of the group of specialists who would start a new chapter in waste management in the municipality. In a clear process of circulation of ideas and network formation, the advisers of the Mayor of the Green Party (PV) at the time met specialist I3 on civil construction waste management. A "transmission belt" (LEITE; PERES, 2015) of I3's technical knowledge in public administration began, as a member of an epistemic community (HAAS, 1992), bringing experience and new ideas generated in his trajectory in the Engineering course at the Polytechnic School of USP, in works at the Technological Research Institute (IPT/USP) and in past technical consultancies in different municipalities.

Still in the 1990s, the City Hall started the process of contracting I\&T consultancy (directed by I3), which triggered a process of mobilizing a network of specialists from other organizations, such as Instituto Gea, whose coordinator graduated from the same school of engineering as I3 and both developed joint work in several municipalities (as reported by interviewee I8). Instituto Gea worked in Guarulhos more specifically in the selective collection policies.

The political articulation between the political actors of the Municipal Executive and specialist actors from the epistemic community went through a process of government change, with the election of the Mayor of the Workers' Party (PT), an opposition candidate, in 2000. This element, which would have the potential to open space for changing the agenda and, in this case, dismantling the ties between actors in the bureaucracy and experts from the previous government, according to Kingdon (2011), reinforced the adherence of the actors of the epistemic community towards changes in the municipal waste policy. The mayor appointed an actor for the Urban Cleaning Department (I4) who had already worked with I\&T consultancy in the municipality of Vitória da Conquista (BA) between 1997 and 2000. An important characteristic of the group under analysis is worth highlighting: the epistemic community of solid waste in Brazil is formed by few 
actors $^{9}$ and the movements and experiences of its members are easily tracked and followed by the respective members.

New ideas that resulted from learning from past experiences were implemented in Guarulhos by the I3 team. The interviews indicated that the main political dispute process took place around the rubble management policy, with the end of the monopoly on the design of cata-trecos in the municipality and the construction of a new balance around the new image (BAUMGARTNER; JONES, 1993), the Voluntary Delivery Points (PEV). The PEV policy, a public policy instrument that shaped the image of this epistemic community, had already been implemented in the municipalities of Santo André, SP and Belo Horizonte, MG. These are signs of transfers of public policies, under the terms of Porto de Oliveira and Pimenta de Faria (2017).

According to interviewees I3 and I4, the idea of PEV was formulated in Santo André in 1980, where it received the name Estação Entulho (Rubble Station), from the identification of waste disposal as a problem in that territory, in the terms of Kingdon (2011). There is a dispute over public policy instruments in this area of construction waste disposal. Before $\mathrm{PEV}^{10}$, the prevailing idea about construction waste management was the cata-treco or cata-bagulho (waste picker), which is characterized by collection carried out by a City Hall truck at households' doors. The two ideas are anchored to different assumptions. If PEV seeks to organize waste disposal, educating the citizens about their responsibilities as generators of waste and ensuring the recycling of materials received, the "waste picker" perpetuates the mistaken understanding that the responsibility for the waste generated is only of the municipality, which works collecting them at people's residences.

In Guarulhos, some of the proponents of cata-treco were councilors and regional administrators ${ }^{11}$, political actors who held strategic positions and crystallized this public policy instrument, vetoing the entry of new ideas into the public administration through the legislative veto to innovations regarding rubble handling and treatment. However, in the midst of the political process led by the network formed between governmental actors of the mayor of the Workers' Party (PT) and the epistemic community in question, the idea of the PEVs gained political support and in 2006 the policy was institutionalized through legislation (Law 6.126/06 that instituted the Integrated Civil Construction Waste Management Plan). The hiring of I\&T consultancy empowered the Municipal Executive in the political dispute process with the Legislative over the technical solution for the rubble produced in the municipality.

In 2004, the Director of I\&T Consultancy (I3) was invited to compose the team of the Ministry of Cities and in 2005 he migrated to the Ministry of the Environment, from which he started to circulate in the national context and to spread ideas and experiences carried out in Guarulhos as a model to be followed in other municipalities. It is a clear

9. For a parameter, the public health epistemic community is broader and older, with national and international groups and organizations acting for decades in the Brazilian context inside and outside government structures.

10. Guarulhos PEVs are public facilities made available to small generators of construction waste, recyclable dry waste and bulky waste.

11. Equivalent to sub-mayor. 
example of how a municipality becomes a platform for transferring policies through the action of a policy entrepreneur configured by the legitimacy of an epistemic community that becomes well known in several subnational governments where it operates.

Some Federal Government publications exemplify this phenomenon. The "Professional guide to the correct management of construction waste" (2005), by the Special Committee on the Environment of the Regional Council for Engineering, Architecture and Agronomy, with support from the Ministry of Cities, published two photos of the PEV in Guarulhos showing good examples of rubble disposal. Publication by the Ministry of the Environment in partnership with the NGO Iclei (Local Governments for Sustainability) entitled "Solid Waste Management Plans: guidance manual" (2012), also cited the example of Guarulhos to show what a place of irregular disposal of waste and then transformed into a PEV was like. In addition, there was a publication by the Ministry of Cities in 2008, entitled "Elements for the organization of selective collection and design of sorting sheds," in which the same model that I\&T brought to Guarulhos is suggested for other municipalities (p. 10).

In 2009, a new administration started in Guarulhos, this time with continuity from the previous political group (Workers party, PT). The political identity of the elected mayor was built around the political banners linked to the environmental defense and basic sanitation, which fed back into the changes that were underway in Guarulhos, towards a new image of public policy. The elected mayor maintained the director of the Urban Cleaning Department (I4) and hired I\&T consultancy again, this time to prepare the Municipal Waste Plan, under the influence of two other waste specialists, with credibility in the national network of actors, who circulated nationally and were very close to the mayor, João and Maria Luiza ${ }^{12}$, consultants from the Ministry of the Environment and knowledgeable about the work of I\&T consultancy in Belo Horizonte in the 1990s.

At that time, the hiring of I\&T consultancy by the city of Guarulhos included Maria Luiza among the experts. At the same time, the mayor appointed a new secretary to monitor the preparation of the Municipal Solid Waste Plan. The appointed secretary, I2, was a former employee of the water and sewage service in Guarulhos and graduated in Sanitary Engineering at the same university and in the same class as Maria Luiza. This finding of proximity of trajectories of actors in the network reinforced the idea that it is a small epistemic community and active in the formulation and implementation of innovative experiences between municipalities.

In 2011, I\&T consultancy delivered the Municipal Solid Waste Plan with guidelines, programs and goals that should guide solid waste management in the municipality for the next 20 years. It was an important institutional milestone, which regulates and constrains actions, regardless of the political group elected. However, if the institutional framework stabilizes practices and procedures, it does not guarantee the absence of political conflict. The interviewees' reports indicate that the dispute between PEV and Cata-Treco remained between Executive and Legislative actors. After the departure of I\&T consultancy, another

12 - João and Maria Luiza are fictitious names, just like the other actors interviewed. As in this case they were not interviewed, they were not coded with the letter I plus a number. 
chapter of power dispute ensued: the Municipal Legislature passed Law No. 7,246/2014, creating the Cata-Treco Program, as an attempt to return to the monopoly of handling rubble in the city. However, the Municipal Executive called the Public Ministry, which defined a legally-flawed initiative and unconstitutionality (Parecer em Ação Direta de Inconstitucionalidade, 2015), issuing an opinion favorable to the Executive. According to the former secretary of public services (I2):

"[...] I think we have made progress in many things in Guarulhos, one of which was the Voluntary Delivery Point (PEV) and not doing the cata-bagulho anymore. We have advanced much more than other cities that have remained in this process. Because it is the citizen's responsibility. He has to take responsibility for the waste he has produced and have the initiative to make the most of his house [during works], reuse and then conscientiously take it to the PEV. And not that old way of the truck passing by and everyone putting out their rubble."

Despite the judicialization of the political conflict over the rubble disposal policy, the Cata-Treco Program is present in the goals of the Guarulhos Solid Waste Master Plan and is carried out by the municipality as necessary, according to I2's testimony:

"I am against cata-bagulho because this creates the question of the resident's conscience, (...) if he produced it, he has to take it to the $\mathrm{PEV}$. But this is not set in stone. For example, we implemented one cata-bagulho at Anita Garibaldi, in an anti-dengue action. It was a neighborhood with a lot of rubble, it was a joint action with the [secretariat of] health, but it was a coordinated action. But it was not meant to institutionalize it in the entire city, as it would be a setback. Whoever is running the cleaning system must have this sensitivity. So, what is the best policy for each situation? How are we going to invest the resources? Is it better to invest in the truck going by people's homes, or is it better to invest in PEV? There is no money for everything, and we know that the cleanest city is the one that dirties the least."

It is interesting to note that the experts from the epistemic community who brought innovations in solid waste management to Guarulhos acted as political actors and produced new meanings of public policy instruments that were previously considered non-negotiable as alternatives for rubble management. With technology defended by actors interested in its continuity, Cata-Treco has become an instrument of action in campaigns to combat dengue, restricting itself to an alternative to be mobilized in a discretionary and ad hoc manner. It was the political process set within the scope of the solid waste subsystem that made this technical change feasible, despite politically based, that is, the change in the image of the rubble policy in Guarulhos. The following table shows a map of the subsystem actors: 
Table 1 - Map of the relationships between the main actors of the solid waste subsystem in Guarulhos:

\begin{tabular}{|c|c|c|}
\hline Actor & Occupation & Main relationships in the solid waste subsystem \\
\hline I1 & $\begin{array}{l}\text { Mayor } \\
\text { of Guarulhos } \\
\text { between } 2001 \\
\text { and } 2008 .\end{array}$ & $\begin{array}{l}\text { - He appointed I4 as Director of Urban } \\
\text { Cleaning in Guarulhos in } 2001 .\end{array}$ \\
\hline $\mathrm{I} 2$ & $\begin{array}{l}\text { Guarul- } \\
\text { hos Public Ser- } \\
\text { vices Secretary }\end{array}$ & $\begin{array}{l}\text { - Appointed by the Mayor elected in } 2009 \text { (PT). } \\
\text { - Personal proximity with Maria Luiza (university } \\
\text { colleague). } \\
\text { - Specialist who starts working in Guarulhos in } \\
2009 .\end{array}$ \\
\hline $\mathrm{I} 3$ & $\begin{array}{l}\text { Director } \\
\text { of I\&T and co- } \\
\text { ordinator of the } \\
\text { epistemic waste } \\
\text { community. }\end{array}$ & $\begin{array}{l}\text { - Actor of great credibility among specialists in con- } \\
\text { struction and demolition waste. } \\
\text { - Provided consultancy several times in Guarulhos. } \\
\text { - Brought the Gea Institute to Guarulhos. } \\
\text { - Worked with Maria Luiza in Belo Horizonte, at the } \\
\text { Ministry of the Environment and in Guarulhos. }\end{array}$ \\
\hline I4 & $\begin{array}{l}\text { Gua- } \\
\text { rulhos Urban } \\
\text { Cleaning Direc- } \\
\text { tor } \\
\end{array}$ & $\begin{array}{c}\text { - Indicated by I1, he approached I3 while work- } \\
\text { ing in Guarulhos, but he already knew him in his } \\
\text { professional career in different municipalities before } \\
\text { working in Guarulhos. }\end{array}$ \\
\hline I8 & $\begin{array}{l}\text { Coordi- } \\
\text { nator at Insti- } \\
\text { tuto Gea }\end{array}$ & $\begin{array}{l}\text { - Personal proximity with I3 (university colleagues). } \\
\text { - Developed works in different municipalities to- } \\
\text { gether with I3. }\end{array}$ \\
\hline Maria Luiza & $\begin{array}{l}\text { Technical } \\
\text { consultant in } \\
\text { the formulation } \\
\text { of the Guarul- } \\
\text { hos Waste Plan }\end{array}$ & $\begin{array}{l}\text { - Personal proximity with I2 (university colleague). } \\
\text { - Consultant at the Ministry of the Environment. } \\
\text { - In the } 1990 \text { s she was Superintendent of Urban } \\
\text { Cleaning in Belo Horizonte, when he contracted } \\
\text { I\&T. }\end{array}$ \\
\hline
\end{tabular}

Source: Prepared by the authors.

\section{Final Remarks}

This work sought to discuss the pioneering political process of the municipality of Guarulhos in the design of the Municipal Solid Waste Plan, mobilizing analytical lenses of public policies. We tried to analyze the process beyond the institutional view, as a response to induction mechanisms produced by the Federal Government. What was 
discussed through this research was the opposite: the construction of the solid waste policy in Guarulhos was a political process of dispute and learning that influenced the federal plan through the circulation of ideas and municipal experiences. It was a process that involved breaking public policy monopolies, in the sense used by Baumgartner and Jones (1993), especially in the case of changing the image of management and rubble handling. The balance around the technology of the cata-treco program has historically been maintained with the articulation of legislative and bureaucratic actors who made use of access to power resources to defend their interests and "freeze" politics.

The entry of new actors, experts from the solid waste epistemic community, into the political and administrative arena unbalanced the monopoly configured in the game of political forces in a municipal context. The shift of new ideas from the plan of the epistemic microsystem to the plan of the political macro-system of Guarulhos was leveraged by the accumulation of credibility and reputation of specialists, true "transmission belts" (LEITE; PERES, 2015), agents of policy transfer processes between municipalities and the federal government, making the result of learning around solid waste policies circulate.

The case of Guarulhos shows the process of combined action between actors in the epistemic community, politicians and municipal managers in changing the solid waste agenda, considering the weight of the action of public policy entrepreneur, in Kingdon's terms (2011). The director of I\&T consultancy fulfilled this role by promoting the use of the windows of opportunities that arose in the process to advance the "new idea," the PEVs, in the midst of the formulation of the Municipal Plan. He was the strategic link that raised new specialists for positions in the municipal public administration and mobilized a political group that was able to stand up to the defenders of the previous monopoly around cata-treco. The institutional advances in the municipality and the circulation of this group later in the federal government are evidence of the political capacity of these actors.

If Guarulhos was an outlet for previous experiences of a group of experts whose trajectory of transferring and circulating ideas qualified them to act as credible political actors in the political context of the municipality, the municipality became a platform for public policies in a subnational and national context after the action of experts, as indicated by the circulation of the Guarulhos experience through the consultancy actions by experts at the Ministry of Cities and the Ministry of the Environment.

The joint action of politicians, specialist consultants and public managers was essential to include the development of the Solid Waste Master Plan on the government's agenda in 2009. This explains a large part of the reasons why Guarulhos was the first municipality to deliver its waste plan to the Ministry of the Environment in 2011, after the approval of the National Solid Waste Policy in 2010. It was a change not induced by federative institutional mechanisms, but through the political process that took place in the municipality in which the political action of experts was crucial. 


\section{Acknowledgments}

To the members of the defense panel of Lígia Gonçalves De Lócco's master's dissertation; to colleagues of the Solid Waste WG of the 1st Southeast Regional Meeting of Anppas, held at the School of Arts, Sciences and Humanities in São Paulo, 2018.

\section{References}

ARRETCHE, M. Democracia, federalismo e centralização no Brasil. Rio de Janeiro: Fundação Getúlio Vargas/Fiocruz, p. 232, 2012.

BALDIN, N.; MUNHOZ, E. M. B. Snowball (Bola De Neve): Uma Técnica Metodológica para Pesquisa em Educação Ambiental Comunitária. In: CONGRESSO NACIONAL DE EDUCAÇÃO, 10., 2011, PUC, Curitiba. Anais eletrônicos. Curitiba: PUC, 2011. Available from: http:// educere.bruc.com.br/CD2011/pdf/4398_2342.pdf. Access on: 02/12/2018.

BARCELOS, M. Uma política social na área de biocombustíveis? A trajetória do Programa Nacional de Produção de Biodiesel (PNPB). Texto apresentado no 39 . Encontro da Anpocs, GT 30 - Políticas Públicas. Caxambu, 2015. Available from: http://anpocs.org/index.php/papers39-encontro/gt/gt30/9726-uma-politica-social-na-area-de-biocombustiveis-a-trajetoria-do-programa-nacional-de-producao-de-biodiesel-pnpb/file. Access on: 10/02/2019.

BARCELOS, M. Processos Sociais, Construções Discursivas e 'Imagens de Política Pública' na Construção da Política de Silvicultura no Rio Grande do Sul. Plural (São Paulo. Online), v. 19, p. 83, 2012.

BAUMGARTNER, F. R. e JONES, B. D. Agendas and instability in American politics. Chicago: University of Chicago Press, 1993.

BÉLAND, D. e COX, R. H. Ideas and Politics in Social Science Research. New York, Oxford University Press, 2011.

BRASIL. Lei no 11.445 , de 5 de janeiro de 2007. Estabelece diretrizes nacionais para o saneamento básico. Available from: <http://www.planalto.gov.br/ccivil_03/_Ato2007-2010/2007/Lei/ L11445.htm >. Access on: 10/12/2018.

BRASIL. Lei no 12.305, de 2 de agosto de 2010. Institui a Política Nacional de Resíduos Sólidos. Available from: <http://www.planalto.gov.br/ccivil_03/_ato2007-2010/2010/lei/112305.htm>. Access on: 10/12/2018.

CAMPBELL, J. L. Institutional analysis and the role of ideas in political economy. Theory and society, 27(3): 377-409, 1998.

CAMPBELL, J. L. Ideas, Politics, and Public Policy. Annual Review of Sociology, 28(1): 21-38, 2002. 
CAPELLA, A. C. N.; BRASIL, F. G. Análise de políticas públicas: uma revisão da literatura sobre o papel dos subsistemas, comunidades e redes. Novos Estudos-CEBRAP, São Paulo, n. 101, p. 57-76, 2015. Available from: < http://www.scielo.br/scielo.php?script=sci_arttext\&pid=S0101$-33002015000100057 \& \operatorname{lng}=\mathrm{pt} \& \mathrm{nrm}=$ iso $>$. Access on: 04/02/2019.

CAPELLA, A. C. N. Um estudo sobre o conceito de empreendedor de políticas públicas: ideias, interesses e mudanças. Cadernos EBAPE.BR, Rio de janeiro, v. 14, p. 486-505, 2016. Available from: <http://www.scielo.br/scielo.php?script=sci_arttext\&pid=S1679. $-39512016000700486 \& \operatorname{lng}=$ pt\&nrm $=$ iso $>$. Access on: 04/02/2019.

DE LÓCCO, Ligia Goncalves. Política de limpeza urbana em Guarulhos: análise da formulação e implementação. 2017. Dissertação (Mestrado em Análise de Políticas Públicas) - Escola de Artes, Ciências e Humanidades, Universidade de São Paulo, São Paulo, 2017. Acesso em: 2020-10-04.

DRYZEK, J. Discursive Democracy: Politics, Policy and Political Science. Cambridge: Cambridge University Press, 1990.

FISCHER, F. e FORESTER, J. The Argumentative Turn in Policy Analysis and Planning. Durham, NC: Duke University Press, 1993.

GOLDSTEIN, J. e KEOHANE, R. O. Ideas and Foreing Policy: Beliefs, Institutions and Political Change. Ithaca, N.Y.: Cornell University Press, 1993.

GRISA, C. Políticas públicas para a agricultura familiar no Brasil: produção e institucionalização das ideias. Tese Doutorado - Instituto de Ciências Humanas e Sociais, Universidade Federal Rural do Rio de Janeiro, Rio de Janeiro, 2012.

GUARULHOS. Prefeitura Municipal. Plano Diretor de Resíduos Sólidos de Guarulhos. 2011. Available from: < http://www.guarulhos.sp.gov.br/pagina/plano-diretor-de-res\%C3\%ADduoss\%C3\%B3lidos $>$. Access on: 11/05/2016.

HAAS, P. M. Introduction: epistemic communities and international policy coordination. International Organization; 46(1): 1-35, 1992.

HALL, P. A. Policy paradigms, social learning and the state: the case of economic policymaking in Britain. Comparative Politics, 25 (3): 275-296, 1993.

HOWLETT, M., RAMESH M., PERL A. Política pública: seus ciclos e subsistemas - uma abordagem integral. Rio de Janeiro: Elsevier; 2013.

KINGDON, J. Agendas, Alternatives, and Public Policies. 3. ed. New York: Harper Collins; 2011.

LEITE, C. K. S.; CRUZ, M. F.; ROSIN, L. B. Difusão da política cicloviária no município de São Paulo: resistências, apoios e o papel da mídia. Revista de Administração Pública RAP, Rio de Janeiro, v. 52, n. 2, p. 244-263, 2018. Available from < http://www.scielo.br/scielo.php?script=sci arttext\&pid $=$ S0034-76122018000200244\&lng $=$ pt\&nrm $=$ iso $>$. Access on: 10/02/2019. 
LEITE, C. K. S.; FONSECA, F. Federalismo e políticas sociais no Brasil: impasses da descentralização pós-1988. Organizações \& Sociedade, Salvador, v. 18, n. 56, p. 99-117, 2011. Available from: $<$ http://www.scielo.br/scielo.php?script $=$ sci_arttext\&pid $=$ S1984-92302011000100005\&lng $=\mathrm{p}$ $\mathrm{t} \& n r m=$ iso $>$. Access on: 04/02/2019.

LEITE, C. K. S.; PERES, U. D. Paradigmas de desenvolvimento e disseminação de políticas: raízes locais da criação do programa bolsa família. Organizações $\mathbb{\&}$ Sociedade, Salvador, v. 22, n. 75, p. 621-638, 2015. Available from: <http://www.scielo.br/scielo.php?script $=$ sci arttext\&pid $=$ S1984-92302015000400621\&lng =en\&nrm $=$ iso $>$. Access on: 04/02/2019.

MACHADO, J. A.; PALOTTI, P. L. M. Entre cooperação e centralização: Federalismo e políticas sociais no Brasil Pós-1988. Revista Brasileira de Ciências Sociais, São Paulo, v. 30, n. 88, p. 61-82, 2015. Available from: <http://www.scielo.br/scielo.php?script=sci_arttext\&pid=S0102. $69092015000200061 \& \operatorname{lng}=\mathrm{pt \& nrm}=\mathrm{iso}>$. Access on: 04/02/2019.

MACHADO, J. A. Federalismo, poder de veto e coordenação de políticas sociais no Brasil pós1988. Organizações $\&$ Sociedade, Salvador, v. 21, n. 69, p. 335-350, 2014. Available from: $<$ http://www.scielo.br/scielo.php?script $=$ sci_arttext\&pid $=$ S1984-92302014000200008\&lng $=p$ t\&nrm=iso $>$. Access on: 04/02/2019.

MAJONE, G. Evidence, Argument and Persuasion in the Policy Process. New Haven: Yale University Press, 1989.

PARECER EM AÇÃO DIRETA DE INCONSTITUCIONALIDADE. Ministério Público, 2015. Available from: http://www.mpsp.mp.br/portal/page/portal/Assessoria_Juridica/Controle_Constitucionalidade/ADIns_3_Pareceres2015/TJ\%20-\%202023496-05.2015.8.26.0000\%20 -\%20GUARULHOS. Access on: 28/02/2019.

PERISSINOTTO, R.; STUMM, M. G. A virada ideacional: quando e como ideias importam. Revista de Sociologia e Política, Curitiba, v. 25, n. 64, p. 121-148, 2017. Available from: < http:// www.scielo.br/scielo.php?script $=$ sci_arttext\&pid $=$ S0104-44782017000400121\&lng $=$ pt\&nrm $=$ iso $>$. Access on: 04/02/2019.

PIMENTA DE FARIA, C. A. (Org.). Implementação de políticas públicas: teoria e prática. Belo Horizonte: PUC Minas, 2012.

PORTO DE OLIVEIRA, O.; PIMENTA DE FARIA, C. A. Policy transfer, diffusion, and circulation: research traditions and the state of the discipline in Brazil. Novos estudos CEBRAP, São Paulo, v. 36, n. 1, p. 13-32, 2017. Available from: < http://www.scielo.br/scielo.php?script=sci_ arttext\&pid=S0101-33002017000100013\&lng=pt\&nrm=iso $>$. Access on: 03/02/2019.

SABATIER, P. A. e JENKINS-SMITH, H. C. Policy change and learning: an advocacy coalition approach. Oxford: Westview Press, 1993.

SOUZA, C. Federalismo, desenho constitucional e instituições federativas no Brasil pós-1988. Revista de Sociologia e Política, Curitiba, n. 24, p. 105-121, 2005. Available from: < http:// www.scielo.br/scielo.php?script $=$ sci_arttext\&pid $=$ S0104-44782005000100008\&lng $=$ pt\&nrm $=$ iso $>$. Access on: 04/02/2019. 
TOMAZINI, C. G.; LEITE, C. K. S. Programa Fome Zero e o paradigma da segurança alimentar: ascensão e queda de uma coalizão? Revista de Sociologia e Política, Curitiba, v. 24, n. 58, p. 13-30, 2016. Available from <http://www.scielo.br/scielo.php? script=sci_arttext\&pid=S0104$-44782016000200013 \& \operatorname{lng}=\mathrm{pt} \& \mathrm{nrm}=\mathrm{iso}>$. Access on: 10/02/2019.

\section{Appendix}

I1: a lawyer and professor of history, he was a councilor in Guarulhos from 1983 to 1990; state deputy from 1990 to 2000 and elected Mayor in Guarulhos in 2000; he ran for mayor again in 2016 but was not elected. Interview held on December 15, 2016, in Guarulhos.

I2: secretary at the Public Services Secretariat between 2009 and 2014, coordinated the preparation of the Guarulhos Waste Master Plan; previously worked at SAAE Guarulhos. Interviews conducted on October 6, 2015 and July 18, 2016, in Guarulhos.

I3: an architect and urban planner from USP, worked at the Technological Research Institute, with a master's and doctorate on recycling of construction waste; director at I\&T Consulting; consulted for several municipalities and the Federal Government. Interview conducted on June 28, 2016, in São Paulo.

I4: worked as manager of waste collection operations at the Municipality of São José dos Campos, SP and coordinator of urban cleaning in Vitória da Conquista, BA; he was Director of Urban Cleaning in Guarulhos from 2001 to 2011; today he works at the Municipal Authority for Urban Cleaning in the city of São Paulo. Interview held on July 20, 2016, in Guarulhos.

I5: director at Quitaúna. Graduated in rainwater drainage at the University of Campinas; has worked at Quitaúna since 1983. Interview conducted on July 26, 2016, in Guarulhos.

I6: a biologist at the Guarulhos City Hall, worked at the Secretariat of the Environment and participated in the elaboration of the Bolsa Família Program and the Municipal Civil Construction Waste Management System; he worked at the Ministry of Health and later returned to Guarulhos, composing the team of the Department of Urban Cleaning. Interview conducted on August 15, 2016, in Guarulhos.

I7: an employee of the Department of Urban Cleaning since when she was part of the Department of Works, Public Services and Works; carried out the inspection, was secretary to the Director and is currently the Manager of Collection of Household Residues and Health Residues. Interview conducted on August 17, 2016, in Guarulhos.

I8: an engineer graduated from USP, as an employee of CETESB she implemented selective collection within the institution, and from this experience she opened an institute with another CETESB employee with a focus on selective collection; currently the Gea Institute develops several works in the country, the most recent being a partnership with USP to train waste pickers on the recycling of electronics. Interview conducted on September 22, 2016, via Skype.

19: an administrator, he has worked for 8 years at the Guarulhos Supply Center. Interview held on July 27, 2016, in Guarulhos. 
E10: worked in the Urban Cleaning Department between 2001 and 2009, responsible for selective collection; she is currently an employee of the Gea Institute. Interview conducted on September 28, 2016, via Skype.

I11: an engineer at the Guarulhos City Hall, he was the Selective Collection Manager at the Urban Cleaning Department between 2009 and 2014. Interview conducted on January 17, 2017, in Guarulhos. 
Cristiane Kerches da Silva Leite

ఐcrisk@usp.br

https://orcid.org/0000-0002-4610-0520
Submitted on: 08/09/2018

Accepted on: 24/03/2020

2020;23:e00242

\section{Lígia Gonçalves De Lócco}

๑ligia.ambiental@gmail.com

https://orcid.org/0000-0003-0291-2962

How to cite: LEITE, C K. S.; DE LÓCCO, L. G Actors, epistemic communities and policy change: analysis of the solid waste policy in Guarulhos (SP). Ambiente \& Sociedade. São Paulo, v. 23, p. 1-18, 2020. 


\title{
Atores, comunidades epistêmicas e mudança política: análise da política de resíduos sólidos em Guarulhos (SP)
}

\author{
Cristiane Kerches da Silva Leite \\ Lígia Gonçalves De Lócco
}

São Paulo. Vol. 23, 2020

Artigo Original
Resumo: Este artigo analisa a formulação e a implementação da política de resíduos sólidos no município de Guarulhos, com ênfase no processo político de disputa de ideias, interesses e instrumentos de políticas públicas entre atores políticos, comunidades epistêmicas e gestores públicos. Esta pesquisa problematiza como o município de Guarulhos foi pioneiro na elaboração do Plano Municipal de Resíduo Sólidos. Objetivou-se articular categorias analíticas da análise de políticas públicas para discutir o papel político de uma rede de atores oriundos da comunidade epistêmica de resíduos sólidos na mudança da política em Guarulhos. Por meio da análise de dados secundários (pesquisa bibliográfica) e primários (decretos, leis, atas de reuniões e entrevistas com atores estratégicos), pode-se verificar o processo de mudança da imagem da política de resíduos sólidos, sobretudo na questão do descarte de resíduos de construção civil, pela ação de transferência e aprendizagem de especialistas agindo como atores políticos no subsistema desta política.

Palavras-chave: Resíduos sólidos; política pública; comunidade epistêmica; imagem de políticas públicas.

Como citar: LEITE, C K. S.; DE LÓCCO, L. G. Atores, comunidades epistêmicas e mudança política: análise da política de resíduos sólidos em Guarulhos (SP). Ambiente \& Sociedade. São Paulo, v. 23, p. 1-18, 2020. 


\title{
Actores, comunidades epistémicas y cambio político: análisis de la política de residuos sólidos en Guarulhos (SP)
}

\author{
Cristiane Kerches da Silva Leite \\ Lígia Gonçalves De Lócco
}

São Paulo. Vol. 23, 2020

Artículo original
Resumen: Este artículo analiza la formulación y la implementación de la política de residuos sólidos en el municipio de Guarulhos, con énfasis en el proceso de disputa de ideas, intereses e instrumentos entre actores políticos, comunidades epistémicas y gestores públicos. Esta investigación problematiza cómo el municipio de Guarulhos fue pionero en la elaboración del Plan Municipal de Residuos Sólidos. Se objetivó articular categorías analíticas de políticas públicas para discutir el papel político de una red de actores de la comunidad epistémica de residuos en el cambio de la política en Guarulhos. Por medio del análisis de datos bibliográficos y primarios (decretos, leyes, actas de reuniones y entrevistas), se puede verificar el proceso de cambio de la imagen de la política de residuos (especialmente en materia de eliminación de residuos de construcción) configurado por la acción de transferencia y aprendizaje de especialistas actuando como actores políticos en el subsistema de esta política.

Palabras-clave: Residuos sólidos; política pública; comunidad epistémica; imagen de políticas públicas.

Como citar: LEITE, C K. S.; DE LÓCCO, L. G. Actores, comunidades epistémicas y cambio político: análisis de la política de residuos sólidos en Guarulhos (SP). Ambiente \& Sociedade. São Paulo, v. 23, p. 1-17, 2020. 